\title{
KARAKTERISASI SIFAT FISIKO KIMIA MINYAK NYAMPLUNG SEBAGAI BAHAN BAKU SABUN PADAT TRANSPARAN
}

\section{PHYSICOCHEMICAL PROPERTIES OF CALOPHYLLUM OIL AS RAW MATERIAL OF TRANSPARENT SOLID SOAP}

\author{
Sri Seno Handayani, Erin Ryantin Gunawan, Dedy Suhendra, Murniati dan I Made Aditha \\ Program Studi Kimia, Fakultas Matematika dan Ilmu Pengetahuan Alam, Mataram, Indonesia \\ e-mail: srihandayani@unram.ac.id
}

Diterima: 23 Agustus 2019. Disetujui: 17 September 2019. Dipublikasikan: 30 September 2020

\begin{abstract}
Abstrak: Penelitian ini merupakan kajian awal tentang pemanfaatan minyak nyamplung (Calophyllum inophyllum) untuk bahan baku pembuatan sabun padat transparan. Minyak nyamplung mengandung berbagai senyawa yang baik untuk kesehatan seperti asam palmitat, asam oleat, asam linoleat dan asam stearat. Minyak biji nyamplung tersebut memiliki aktivitas antibakteri terhadap Staphylococus aureus sehingga Minyak tersebut sangat bermanfaat untuk kesehatan kulit. Tujuan dari penelitian ini adalah untuk mengetahui sifat fisiko kimia minyak nyamplung serta karakterisitik kualitas sabun padat transparan dari minyak tersebut. Penelitian ini dilakukan dalam beberapa tahap yaitu isolasi minyak, uji sifat fisik dan kimia minyak, analisis kandungan senyawa minyak menggunaan GCMS serta formulasi sabun padat transparan dari minyak nyamplung. Hasil penelitian menunjukkan bahwa rendemen minyak nyamplung diperoleh sebesar $54.96 \%$ dengan bilangan asam $64.141 \mathrm{mg} \mathrm{KOH} / \mathrm{g}$ minyak, bilangan penyabunan $153.293 \mathrm{mgKOH} / \mathrm{g}$ minyak dan bilangan iod $160.31 \mathrm{iod} / 100 \mathrm{~g}$ minyak. Selain itu, diperoleh densitas dan viskositas minyak nyamplung berturut-turut adalah $0.822 \mathrm{gr} / \mathrm{mL}$ dan 0.35 cSt. Sabun yang diperoleh, dilakukan uji kualitas sabun. Hasil uji kualitas menunjukkan bahwa karakter sabun nyamplung tersebut sudah memenuhi standar SNI.
\end{abstract}

Kata kunci: sifat fisiko kimia, minyak nyamplung, sabun padat

\begin{abstract}
This research is a preliminary research on the use of the Calophyllum inophyllum oil for the raw material for making transparent solid soap. The Calophyllum inophyllum oil contains various compounds that are good for health such as palmitic acid, oleic acid, linoleic acid, and stearic acid. The seed of Calophyllum inophyllum has antibacterial activity against Staphylococcus aureus so that the oil is very beneficial for skin health. The purpose of this research was to determine the physicochemical properties of Calophyllum inophyllum oil for preparation as a transparent solid soap raw material. This research was carried out in several stages, namely oil isolation, physical and chemical properties test of oil, analysis of the content of oil compounds using GCMS, and formulation of transparent solid soap of Calophyllum inophyllum oil. The results showed that we obtained 54.96\% oil of Calophyllum inophyllum with an acid number $64.141 \mathrm{mg} \mathrm{KOH} \mathrm{/} \mathrm{g}$ oil, saponification number $153.293 \mathrm{mgKOH} / \mathrm{g}$ oil, and iodine number $160.31 \mathrm{iod} / 100 \mathrm{~g}$ oil. In addition, we obtained that Calophyllum inophyllum oil density and viscosity are $0.822 \mathrm{gr} / \mathrm{mL}$ and $0.35 \mathrm{cSt}$, respectively. The soap obtained is tested for the quality. We have that the character of the soap of Calophyllum inophyllum had satisfied the SNI standard.
\end{abstract}

Keywords: physico-chemical properties, Calophyllum inophyllum oil, solid soap

\section{PENDAHULUAN}

Sabun merupakan persenyawaan dari natrium dan kalium dengan asam lemak nabati atau hewani yang berfungsi sebagai pembersih. Eksplorasi sediaan bahan baku sabun yang murah dan aman bagi kesehatan sangat diperlukan mengingat sampai saat ini bahan baku yang digunakan masih mengandalkan minyak pangan dan mahal seperti minyak kelapa, minyak zaitun dll. Penggunaan bahan-bahan kimia yang sifatnya berbahaya bagi kesehatan seperti DEA, sodium lauryl sulfate dan triclosan dalam sabun mandi pasaran masih tetap dilakukan untuk meningkatkan karakter sabun.

Sabun memiliki sifat menurunkan tegangan permukaan sambil mengemulsi kotoran. Sabun yang terikat pada air akan mengikat kotoran sehingga melarutkan kotoran-kotoran pada kulit. Pada penelitian ini pemilihan minyak nyamplung sebagai bahan baku sabun memiliki beberapa alasan, antara lain untuk meningkatkan nilai ekonomis minyak nyamplung serta substitusi minyak pangan untuk bahan baku sabun. Biji berbentuk bulat tebal dan keras, berukuran relatif besar berdiameter $2.5-4 \mathrm{~cm}$, daging biji tipis dan biji yang telah kering dapat tahan disimpan selama 1 bulan, inti biji mengandung minyak berwarna kuning kecoklatan [5]. Menurut Chasani, dkk [3] sabun nyamplung memiliki aktivitas antibakteri terhadap Staphylococus aureus. Alamsyah, dkk [1] menyatakan bahwa minyak nyamplung mengandung asam palmitat $14.60 \%$, asam oleat 
$37.57 \%$, asam linoleat $26.33 \%$ dan asam stearate $19.96 \%$ yang sangat bermanfaat untuk kesehatan kulit. Sedangkan menurut Suyono, dkk [10] rendemen minyak nyamplung dapat mencapai 40$70 \%$ dan tergolong tinggi dibandingkan jarak pagar dan sawit. Minyak nyamplung dapat diperoleh melalui berbagai proses ekstraksi, salah satunya adalah metode sokletasi. Kelebihan metode sokletasi dibandingkan dengan metode ekstraksi yang lain adalah minyak dapat terekstrak sempurna dengan jumlah pelarut yang relatif sedikit.

Pada penelitian ini bahan baku untuk pembuatan sabun adalah minyak nyamplung. Tujuan dari penelitian ini adalah mengetahui karakterisasi minyak nyamplung sebagai bahan baku sabun padat transparan. Sabun mandi transparan adalah salah satu produk inovasi sabun yang menjadikan sabun menjadi lebih menarik. Sabun transparan mempunyai busa yang lebih halus dibandingkan dengan sabun opaque (sabun yang tidak transparan) [8]. Pembuatan sabun dari minyak nyamplung dilakukan dalam dua tahap, yaitu tahap proses saponifikasi dan tahap netralisasi. Pada proses saponifikasi akan terjadi reaksi antara trigliserida dengan alkali, sedangkan proses netralisasi terjadi reaksi asam lemak bebas dengan alkali. Proses saponifikasi akan menghasilkan sabun dan gliserol sebagai hasil samping.

\section{METODE PENELITIAN}

Bahan yang digunakan adalah buah nyamplung, etanol, $\mathrm{KOH}, \mathrm{NaOH}, \mathrm{HCl}, \mathrm{H}_{2} \mathrm{SO}_{4}$, $\mathrm{NaCl}$, dietileter, $\mathrm{CCl}_{4}$, pereaksi Hanus, indikator fenolftalein, $\mathrm{Na}_{2} \mathrm{~S}_{2} \mathrm{O}_{3}$, larutan KI, gliserin, sukrosa, indikator metil jingga, larutan kanji, batu didih, dan aquades. Peralatan yang digunakan adalah alat gelas, rotary evaporator, alat soklet, alat refluks, magnetik stirer, timbangan analitik, cetakan sabun. Penelitian ini terdiri dari beberapa tahap yaitu, tahap preparasi sampel, tahap ekstraksi minyak, uji sifat fisio kimia minyak, tahap pembuatan sabun dan tahap uji kualitas sabun.

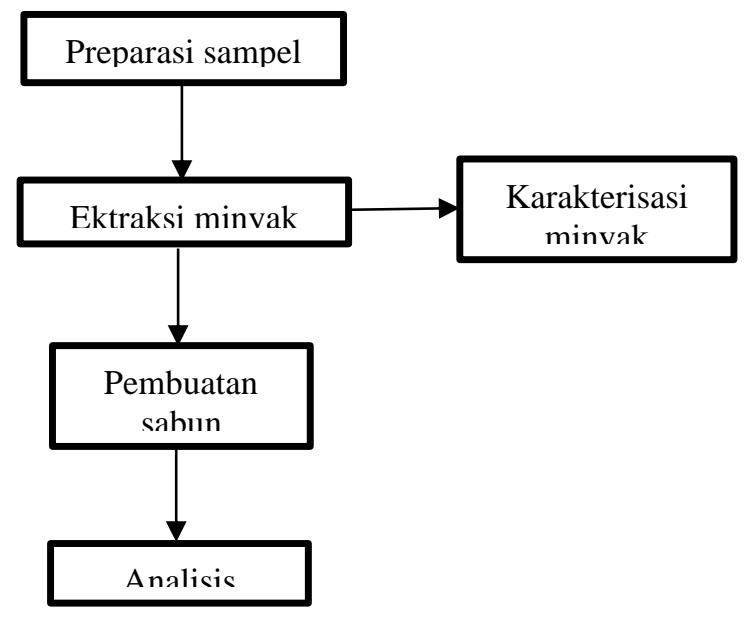

\section{Preparasi Sampel}

Buah nyamplung yang sudah bersih dan kering diblender dan diayak. Serbuk biji kemudian diukur kadar airnya.

\section{Pengukuran Kadar Air}

Kadar air ditetapkan dengan metode oven. Biji nyamplung dan dipotong kecil-kecil, kemudian ditimbang lalu dioven selama 2 jam dengan suhu $105^{\circ} \mathrm{C}$. Didinginkan dalam desikator selama 15 menit. Sampel yang sudah kering lalu ditimbang. Pengeringan dilakukan berulang-ulang hingga didapatkan berat kering yang konstan.

\section{Ekstraksi Minyak Nyamplung}

Pada penelitian ini, ekstraksi minyak nyamplung dilakukan dengan metode sokletasi selama 6 jam diatas penangas air menggunakan pelarut nheksana. Minyak hasil ekstraksi dipisahkan dari pelarutnya menggunakan rotary evaporator pada suhu $40{ }^{\circ} \mathrm{C}$ dengan kecepatan $120 \mathrm{rpm}$ sehingga akan diperoleh minyak murni yang berwarna kuning bening. Minyak yang diperoleh kemudian ditimbang untuk ditentukan kadarnya, dan selanjutnya ditambahkan Natrium sulfat anhidrat untuk menghilangkan kadar airnya.

\section{Uji Sifat Fisiko Kimia Minyak Nyamplung}

Uji sifat minyak dilakukan berdasarkan metode SNI [2], meliputi penentuan kadar minyak, penentuan bilangan penyabunan, penentuan bilangan asam, dan penentuan bilangan iodium, densitas dan viskositas.

\section{Pembuatan Sabun}

Minyak nyamplung sebanyak $30 \mathrm{gr}$ dimasukkan kedalam erlenmayer kemudian dipanaskan dalam penangas air sambil diaduk dengan magnetic stirer. Lalu ditambahkan dengan $10 \mathrm{~mL} \mathrm{NaOH} 30 \%$ dan $30 \mathrm{~mL}$ etanol. Campuran kemudian dipanaskan sambil diaduk dengan kecepatan sedang sampai semua lemak tersabunkan (ditandai dengan tidak adanya lapisan minyak yang tidak bercampur ketika pengadukan dihentikan). Campuran sabun kemudian ditambahkan $10 \mathrm{gr}$ gliserin, $10 \mathrm{~mL}$ sukrosa $50 \%$, dan $5 \mathrm{~mL} \mathrm{NaCl}$ jenuh sambil terus diaduk sampai mengental. Setelah semuanya homogen, campuran dimasukkan dalam cetakan dan didiamkan sampai kering. Ditunggu satu minggu untuk proses pengujian sabun.

\section{Uji Kualitas, Keamanan, dan Efektivitas Sabun Mandi \\ Uji kualitas sabun yang dihasilkan sesuai dengan SNI 3532-2016 [2].}

Gambar 1. Diagram Alir Penelitian 


\section{HASIL DAN PEMBAHASAN \\ Persiapan Bahan Baku}

Sampel yang digunakan pada penelitian ini adalah buah nyamplung yang diperoleh dari daerah Lombok Barat. Buah yang digunakan adalah buah yang sudah tua dan jatuh dari pohonnya. Pada umumnya buah yang telah tua memiliki kandungan minyak yang lebih tinggi dengan kandungan air yang rendah.

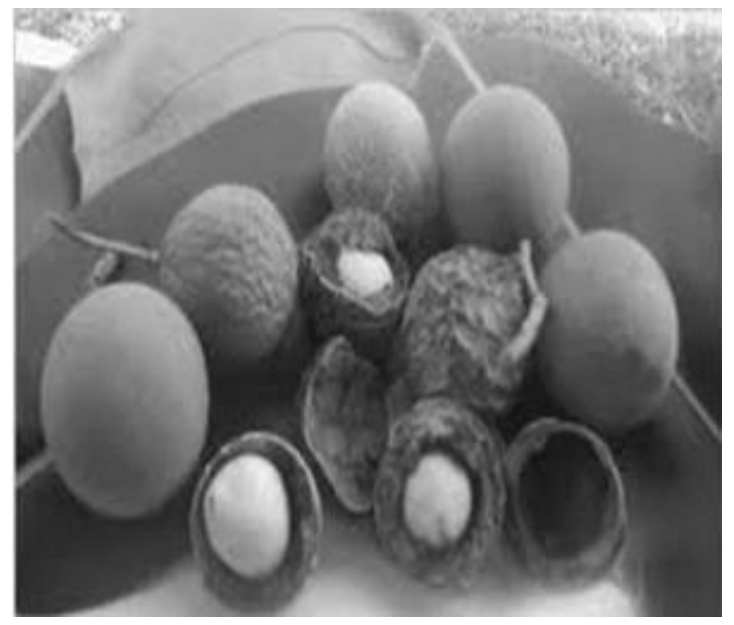

Gambar 2. Buah Nyamplung

Buah nyamplung yang telah terkumpul selanjutnya dikupas untuk mendapatkan inti buah nyamplung. Inti buah nyamplung yang telah diperoleh kemudian disortir.

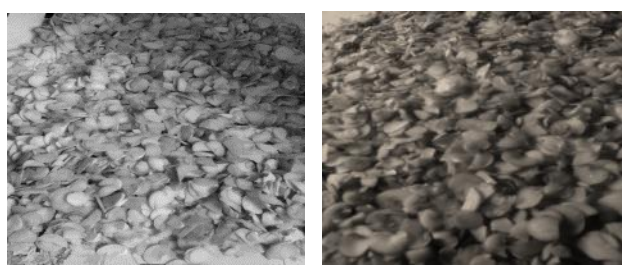

Gambar 3.Inti Buah Nyamplung

Berdasarkan hasil pengukuran, diperoleh berat inti buah nyamplung berkisar antara 3-4 gram dengan kadar air adalah $32.45 \%$.

\section{Ekstraksi Minyak Nyamplung}

Proses ekstraksi bertujuan untuk menarik minyak yang ada di dalam sampel. Pada penelitian ini, ekstraksi minyak nyamplung dilakukan dengan metode sokletasi. Metode ekstraksi sokletasi memiliki berberapa kelebihan antara lain, hasil ekstrak yang dihasilkan lebih banyak dan penggunaan pelarut dan waktu yang lebih efisieni. Ekstraksi akan berjalan lebih sempurna karena dilakukan berulang-ulang. Pelarut yang digunakan adalah n-heksana dikarenakan sifat non-polar dari n-heksana sehingga sangat baik sebagai pelarut minyak.

Proses sokletasi berlangsung selama 6 jam dengan prinsip pelarut $\mathrm{n}$-heksan yang dipanaskan akan menguap dan uap pelarut akan terkondensasi menjadi molekul-molekul oleh pendingin balik dan turun kembali membasahi sampel serbuk nyamplung yang terbungkus kertas saring, sehingga pelarut yang jatuh ke sampel merupakan pelarut murni, selanjutnya masuk kembali dalam labu alas bulat setelah melewati pipa. Sampel yang terendam dengan pelarut yang telah terkondensasi akan jatuh kembali setelah mencapai ketinggian tertentu pada alat tersebut dan akan turun kembali ke labu alas bulat dan diuapkan kembali, sehingga terjadi ekstraksi secara kontinyu dan prosesnya terjadi secara berkesinambungan.

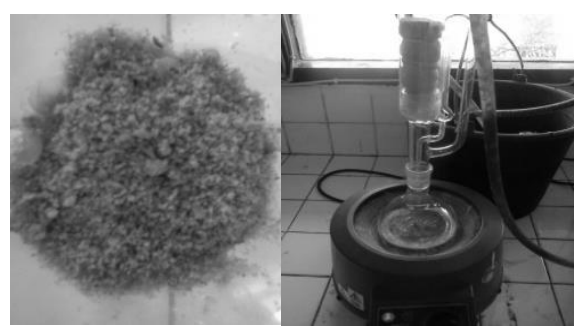

Gambar 4. Ekstraksi

Hasil sokletasi kemudian dievaporasi menggunakan alat Rotary Evaporator yang memiliki prinsip penguapan pelarut dengan pemanasan yang dipercepat oleh putaran labu alas bulat. Uap pelarut akan menguap naik ke kondensor dan mengalami kondensasi menjadi molekul-molekul cairan pelarut murni yang ditampung ke dalam labu penampung alas bulat. Minyak hasil evaporasi kemudian ditambahkan Natrium Sulfat Anhidrat dengan tujuan untuk menghilangkan air yang mungkin masih terdapat didalam minyak. Minyak inti buah nyamplung yang diperoleh berwarna kuning bening.

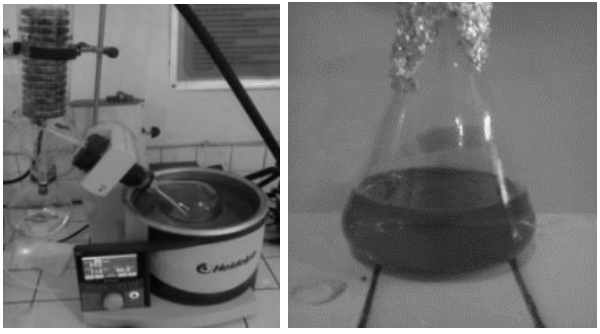

Gambar 5. Evaporasi Minyak Nyamplung

Proses sokletasi dilakukan sebanyak 3 kali pengulangan dan diperoleh rendemen minyak nyamplung sebesar $54.96 \%$. Kadar ini lebih tinggi dibandingkan minyak jarak yang memiliki kadar minyak $30-50 \%$ [6].

\section{Karakterisasi Minyak Nyamplung}

Sifat fisika dan kimia minyak nyamplung hasil ekstraksi dianalisis untuk mendapatkan karakterisasi minyak nyamplung yang terdiri dari bilangan asam, bilangan iod, bilangan penyabunan, densitas, viskositas, dan warna. Hasil analisis 
menunjukkan bahwa bilangan asam minyak nyampung adalah $64.141 \mathrm{mg}-\mathrm{KOH} / \mathrm{g}$ minyak dan tergolong tinggi dibandingkan minyak jarak yang memiliki bilangan asam $4.75 \mathrm{mg}-\mathrm{KOH} / \mathrm{g}$ [9]. Bilangan asam merupakan ukuran dari jumlah asam lemak bebas, dihitung berdasarkan berat molekul dari asam lemak atau campuran asam lemak. Bilangan asam menunjukkan jumlah miligram $\mathrm{NaOH}$ yang dibutuhkan untuk menetralkan asam lemak bebas. Hal ini akan sangat tergantung dari kemurnian dan umur dari minyak tersebut. Bilangan asam yang besar menunjukkan asam lemak bebas yang besar pula, yang berasal dari hidrolisa minyak atau lemak, ataupun karena proses pengolahan yang kurang baik. Kandungan asam lemak bebas yang tinggi dari minyak nyamplung membuat minyak ini tidak baik untuk dijadikan minyak pangan.

Bilangan iod minyak nyamplung hasil penelitian menunjukkan angka $160.31 \mathrm{Iod} / 100 \mathrm{~g}$ minyak. Bilangan ini mencerminkan kadar ketidakjenuhan asam lemak penyusun minyak atau lemak. Banyaknya iod yang dapat diikat oleh minyak atau lemak menunjukkan jumlah ikatan rangkap yang ada pada minyak atau lemak tersebut. Bilangan iod digunakan untuk menentukan ketidakjenuhan suatu minyak. Menurut [4] bilangan iod dinyatakan sebagai jumlah gram iod yang diserap oleh 100 gram minyak atau lemak. Penentuan bilangan iod pada penelitian ini dilakukan menggunakan metode wijs dengan cara menambahkan larutan iodine monoklorida dalam campuran asam asetat dan karbon tetraklorida kedalam sejumlah sampel yang akan diuji [7].

Berdasarkan besarnya bilangan iodin menunjukkan bahwa minyak nyamplung merupakan trigliserida yang tersusun atas asam lemak tidak jenuh rantai panjang.

Tabel 1. Karakterisasi Minyak Nyamplung

\begin{tabular}{lc}
\hline \multicolumn{1}{c}{ Parameter } & Hasil penelitian \\
\hline Minyak & $54.96 \%$ \\
Bil. Iod & $160.31 \mathrm{Iod} / 100 \mathrm{~g}$ \\
& minyak \\
Bil. Asam & $64.141 \mathrm{mg}-\mathrm{KOH} / \mathrm{g}$ \\
& $\mathrm{minyak}$ \\
Bil. Penyabunan & $153.293 \mathrm{mgKOH} / \mathrm{g}$ \\
& minyak \\
Densitas & $0.822 \mathrm{~g} / \mathrm{ml}$ \\
Inti buah & $38.66 \%$ \\
Selulosa & - \\
Viskositas & $0.35 \mathrm{cSt}$ \\
\hline
\end{tabular}

\section{Uji Kualitas Sabun}

Uji kualitas sabun padat dilakukan dengan menggunakan metode SNI 3532-2016 yang meliputi kadar air, total asam lemak, bahan tak larut dalam etanol, kadar asam lemak bebas atau alkali bebas, kadar klorida, lemak tidak tersabunkan, dan uji $\mathrm{pH}$.

Tabel 2. Karakterisasi Sabun Minyak Nyamplung

\begin{tabular}{|c|c|c|}
\hline $\begin{array}{c}\text { Hasil Analisis } \\
(\%)\end{array}$ & $\begin{array}{c}\text { Sabun } \\
\text { nyamplung }\end{array}$ & $\begin{array}{c}\text { Syarat mutu } \\
\text { SNI-3532- } \\
2016\end{array}$ \\
\hline Kadar Air & 9.49 & Maksimal 15.0 \\
\hline $\begin{array}{l}\text { Total Asam } \\
\text { Lemak }\end{array}$ & 71.157 & Minimal 65.0 \\
\hline Bahan Tak & & \\
\hline $\begin{array}{l}\text { Larut Dalam } \\
\text { Etanol }\end{array}$ & 0.433 & Maksimal 5.0 \\
\hline $\begin{array}{c}\text { Asam Lemak } \\
\text { Bebas }\end{array}$ & - & Maksimal 2.5 \\
\hline Alkali Bebas & 0.12 & Maksimal 0.1 \\
\hline Kadar Klorida & - & Maksimal 1.0 \\
\hline $\begin{array}{l}\text { Lemak Tidak } \\
\text { Tersabunkan }\end{array}$ & 0.964 & Maksimal 0.5 \\
\hline $\mathrm{pH}$ & 10.32 & - \\
\hline
\end{tabular}

\section{PENUTUP}

Kesimpulan

Berdasarkan hasil dari penelitian ini, dapat ditarik kesimpulan bahwa :

1. Berdasarkan sifat fisiko kimia, minyak nyamplung merupakan trigliserida yang tersusun atas asam lemak tak jenuh rantai panjang sehingga sangat berpotensi untuk dijadikan sebagai bahan baku sabun.

2. Hasil penelitian diperoleh sifat fisiko kimia minyak nyamplung adalah sebagai berikut: rendemen minyak $54.96 \%$, bilangan asam 64.141 dan bilangan iod 160.31. Densitas dan viskositas minyak nyamplung hasil penelitian diperoleh 0.822 $\mathrm{gr} / \mathrm{mL}$ dan $0.35 \mathrm{cSt}$.

3. Berdasarkan uji kualitas sabun yang telah dilakukan sebagian karakter sabun sudah memenuhi standar, kecuali untuk $\mathrm{pH}$ sabun yang masih tinggi.

\section{Saran}

Adapun beberapa saran untuk penelitian selajutnya, yaitu:

a. Perlu dilakukan kajian pembuatan sabun nyamplung dengan berbagai kombinasi bahan aktif alami lain.

b. Perlu dilakukan optimasi kembali pada formulasi sabun sehingga diperoleh karakter sabun dengan $\mathrm{pH}$ yang memenuhi standar.

\section{DAFTAR PUSTAKA}

[1] Alamsyah, R., \& Lubis, E. H. (2012). Pengolahan Biodiesel dari Biji Nyamplung (Calophyllum Inophyllum L) Dengan Cara Purifikasi Kering. Jurnal Kimia dan Kemasan, 34(2), 287-294.

[2] Badan Standarisasi Nasional Indonesia, (2016). Sabun Mandi Padat, SNI 3532: 2016, Jakarta: Dewan Standar Nasional 
[3] Chasani,M.,Widyaningsih,S.,Mubarok, A. (2015). Synthesis And Characterization Of Sodium Soap From Nyamplung Seed Oil (Calophyllum Inophyllum L.) And Test Antibacterial Activity Against Staphilococus Aureus. Jurnal Molekul, Vol. 10. No. 1. 66 73

[4] Ketaren, (1986). Minyak dan Lemak Pangan, Universitas Indonesia Press, Jakarta.

[5] Leksono, B.,Windyarini,E., Hasnah, M.T. (2014). Budidaya Nyamplung (Calophyllum Inophyllum L.) Untuk Bioenergi Dan Prospek Pemanfaatan Lainnya. Balai Besar Penelitian Bioteknologi dan Pemuliaan Tanaman Hutan. IPB Press.

[6] Muderawan, I.W., Daiwataningsih, N.K.P. (2016). Pembuatan Biodiesel Dari Minyak Nyamplung (Calophyllum Inophylum L.) dan Analisis Metil Esternya dengan GC-MS. Prosiding Seminar Nasional MIPA FMIPA Undiksha

[7] Paquot, C., Hautfenne, A. (1987). Standart Method for Analysis of Oils, Fat and Derivatives Seventh Resived and Enlarge Edition. California : Black Scientific Publication.

[8] Sukeksi, Lilis., Meirany, S., dan Lionardo, S. (2018. Pembuatan Sabun Transparan Berbasis Minyak Kelapa Dengan Penambahan Ekstrak Buah Mengkudu (Morinda Citrifolia) Sebagai Antioksidan. Jurnal Teknik Kimia. No. 2, Vol. 7

[9] Said, M., Belinda, A., Saputra, A. 2009. Pembuatan Biodiesel Dari Minyak Jarak Pagar dengan Katalis $\mathrm{NaOH}$. Jurnal Teknik Kimia, No. 1, Vol. 16

[10] Suyono; Hartanti, N.U, Wibowo, A dan Narto. (2017.) Biodisel dari Mangrove Jenis Nyamplung (Callophylum inophyllum) sebagai Alternatif Pengganti Bahan Bakar Minyak Fosil. Biosfera. Vol. 34(3) 